\title{
DOES CORPORATE SOCIAL RESPONSIBILITY AFFECT THE PARTICIPATION OF MINORITY SHAREHOLDERS IN CORPORATE GOVERNANCE?
}

\author{
Dongmin Kong \\ School of Economics, Huazhong University of Science and Technology, China \\ Luoyu Road 1037\#, Wuhan 430074, China \\ Sun Yat-sen Business School, Sun Yat-sen University, China, Guangzhou 510275, China \\ E-mail:kongdm@mail.hust.edu.cn
}

Received 23 March 2012; accepted 09 July 2012

\begin{abstract}
Using a unique minority shareholders voting dataset, we aim to shed light on several important issues on corporate governance and investor protection. Specifically, we first examine the effects of social responsibility $(C S R)$ on minority shareholder participation $(M S P)$. Then, we investigate whether the mounting attention to CSR due to certain events has marginal effects on MSP, and whether CSR and MSP affect firms' market performances. Collectively, we find that: 1) firms' CSR levels significantly affect $M S P$ and can substitute the governance role of minority shareholders to some extent; 2) exogenous shocks related to CSR can significantly affect $M S P$; and 3) firms with higher $C S R$ level and lower MSP enjoy higher market value improvements. In addition, we find limited evidence that institutional investors may face conflict-of-interest pressures and vote against individual investors. Our results are robust to alternative specifications and offer significant policy implications.
\end{abstract}

Keywords: corporate social responsibility, minority shareholder participation, online voting, China's stock market.

Reference to this paper should be made as follows: Kong, D. 2013. Does corporate social responsibility affect the participation of minority shareholders in corporate governance?, Journal of Business Economics and Management 14(Supplement 1): S168-S187.

JEL Classification: M14, G34, G38.

\section{Introduction}

In this paper, by introducing a natural experiment in China, we investigate how corporate social responsibility (CSR) affects the participation of minority shareholders in corporate governance. Hill et al. (2007) define CSR as the economic, legal, moral, and philanthropic actions of firms that influence relevant stakeholders. McWilliams and Siegel (1997) point out that while the definition of CSR may vary across organizations, it generally refers to "actions that appear to further some social good, beyond the interests of the firm and that which is required by law". The rapid growth in firms' activities associated with CSR has been one of the most significant corporate trends. Recently, a 
larger number of companies engage in efforts to integrate CSR into all aspects of their businesses worldwide. Meanwhile, an increasing number of shareholders, analysts, regulators, employees, and news media are paying more attention than ever to CSR issues of companies. Although ongoing debate remains as to whether good CSR performance indeed contributes to firms' success (e.g., Posnikoff 1997; Wright, Ferris 1997) ${ }^{1}$, no doubt remains about the damage bad CSR can do to a firm. Generally, previous studies document links between $C S R$ and profitability, corporate governance, investors' preferences, ownership structure, firm size, leverage, employees, industry, and environmental pressures (Deniz-Deniz, Garcia-Falcon 2002; Graves, Waddock 1994; Wang et al. 2010; Li, Zhang 2010; Johnson, Greening 1999; Stanwick, Stanwick 1998; Zu, Song 2009).

Protection of minority shareholders is also an important issue in corporate governance literature. Minority shareholders typically hold low amounts of stocks; benefits gained from their participation in shareholder meetings are thus very asymmetric to the cost. Therefore, minority shareholders usually vote by foot or are merely "free riders". A common solution to this agency conflict is to design monitoring mechanisms (e.g., board of directors and auditors) to reduce conflicting interests between minority shareholders and majority shareholders. Due to the failure of many common monitoring mechanisms, interest has grown among activist minority shareholders in shifting the corporate decision-making power from majority shareholders or insiders to minority shareholders (e.g., Vascellaro, Tibken 2008). For instance, Bebchuk (2005) argues that granting minority shareholders direct control over corporate decisions is necessary to combat widespread agency problems of insiders and to increase shareholder value. However, numerous studies in this field only emphasize the monitoring role of institutional investors and largely neglect the potential role of monitory shareholders. Gillan and Starks (2007) offer an excellent review of shareholder activism in the United States.

In addition, regulators worldwide are exhibiting increasing eagerness to propose regulations and are busy enacting new laws to strengthen monitoring mechanisms that grant minority shareholders direct control over corporate decisions (e.g., Scannell 2009; Chen et al. 2013).

Considering the above concerns, some interesting questions arise. Given that CSR is one of the most significant corporate trends, whether it affects minority shareholder participation in decisions of the firm is a pertinent concern. If CSR indeed matters, does it enhance or weaken the participation of minority shareholders? Furthermore, does the mounting attention to CSR have marginal effects on this relationship?

\footnotetext{
${ }^{1}$ Studies on CSR and firm performance in financial markets report mixed and inconclusive findings (Ullman 1985; McWilliams, Siegel 1997; Godfrey 2005) even though some investors (e.g., socially responsible investment funds) explicitly favor firms that are socially responsible. For example, some researchers detect a positive relationship (e.g., Posnikoff 1997), some discover a negative relationship (e.g., Wright, Ferris 1997), and others find no relationship (e.g., Teoh et al. 1999; Surroca, Tribo, Waddock 2010). Griffin and Mahon (1997) find that the inconclusive findings in the existing literature can be attributed to inconsistent empirical proxies and constructs in previous studies. Others suggest that relationship between corporate charitable contributions and firm performance can be rather complex and new theory and refined research designs are needed to capture the complexity underlying firms' decisions for charitable giving (Godfrey 2005).
} 
Although answers to these questions have significant implications in practice and in the academe, no related study, to the best of our knowledge, has presented direct evidence on this issue. The difficulty of studying these questions can be derived from data limitation. Specifically, the data on minority shareholder participation is not accessible for most researchers. Thus, difficulties arise in constructing the variable serving as a proxy for minority shareholders' participation. For instance, Smaliukiene (2007) emphasizes stakeholder attitudes regarding corporate environmental responsibility in different countries and how these attitudes are reflected in business practice.

To fill the gap, this paper provides direct evidence on how CSR affects minority shareholder participation in corporate decisions by using unique data (i.e., the minority shareholders' online voting data in Shenzhen Exchange market (SZSE)). Here, minority shareholders primarily refer to individual investors, because SZSE and China Securities Regulatory Commission (CRSC) only offer the online voting system to individual investors. Meanwhile, the data from China allow us to conduct two additional tests. First, by introducing China's melamine contamination incident in 2008 as a natural experiment, we also examine the marginal effects of $C S R$ on minority shareholder participation in an exogenous event. Second, given that share structures of firms in China differ from their counterparts in developed countries (see Tian, Estrin 2008; Li, Zhang 2010), we examine whether ownership structure affects the relationship between CSR and minority shareholders' participation in a typical emerging market.

Accordingly, this paper offers several important contributions. First, we contribute to a growing corporate governance literature. The unique data (minority shareholders' online voting records in SZSE) allow us to conduct a direct test to investigate how CSR or other factors affect the degree of minority shareholders' participation in corporate governance. Therefore, questions on the governance role of minority shareholders can be answered, distinguishing us from other indirect tests (Davis, Kim 2007; Cremers, Romano 2009; Chen et al. 2013).

Second, we contribute understanding of the governance role of minority shareholders in emerging markets with weak country-level investor protections ${ }^{2}$. Despite the potential agency conflicts that may hinder minority shareholder participation in corporate governance, our results suggest that minority shareholders can strengthen the corporate governance of listed firms in countries with weak investor protections. Chen et al. (2013) present evidence indicating that mutual funds play a similar role.

Third, although CSR is a part of business schemes, most related studies only focus on effects of CSR on firms' performance or investors' preferences; the reported findings are

\footnotetext{
2 The weak investor protection in China is due to two reasons. First, many laws are not effectively enforced in China, and severe interest conflict occurs between "fair play" in practicing law and the monopoly power of the single ruling party, especially in cases in which government officials or their affiliates are involved. Second, China's financial and accounting system is far from mature, and the most important problem in China's accounting system is the lack of independent, professional auditors. Allen et al. (2005) argue that this implies that the accounting standards may be counterproductive within China's current infrastructure: With few auditors understanding and enforcing these standards, and given the lack of an effective judicial system, embezzlement of company assets and other forms of fraud may occur frequently.
} 
mixed. Some researchers detect a positive relationship (e.g., Posnikoff, 1997), whereas some discover observe a negative relationship (e.g., Wright, Ferris 1997) and others find no relationship (e.g., Teoh et al. 1999). In this paper, we offer a new test to explore the relation between CSR and minority shareholders' participation in corporate governance when combined with other factors.

Fourth, we observe the negative effects of CSR on minority shareholders' participation. This finding offers critical insight for regulators, particularly in finding a substitutive channel (i.e., enhancing the CSR level) to protect the profit of minority shareholders in countries with weak investor protections. Our results also provide timely empirical evidence for government regulators who are concerned about costs and benefits of granting minority shareholders direct control over corporate decisions.

Last, by introducing a natural experiment in China that shifted public attention to CSR, we document that the mounting attention to CSR due to events has marginal effects on the relationship between minority shareholder participation and CSR.

In this paper, we conduct three types of empirical analyses using minority shareholders' online voting data of SZSE and the listed firms' social responsibility ranking, released by Shanghai National Accounting Institute of China (SNAI). First, we employ regressions to test whether CSR affects minority shareholders' online participation after controlling for other factors potentially affecting investor participation. Second, by introducing China's melamine contamination incident in 2008 as a natural experiment, we examine the marginal effect of a CSR-grabbing event on the relationship between $C S R$ and minority shareholder participation. Last, we employ regressions to answer important questions related to $C S R$ and minority shareholder voting behavior, such as whether $C S R$ and minority shareholder voting participation in corporate governance are correlated with market reactions.

Correspondingly, our primary results can be summarized as follows: 1) Firms' CSR levels significantly affect minority shareholder participation in reverse, and CSR can substitute the governance role of minority shareholders to a certain extent; 2) exogenous shock-related CSR can significantly affect the participation of minority shareholders by eliciting public attention; 3) firms with higher CSR levels and lower participation rates of minority shareholder voting undergo higher market value improvement and increased positive market reaction in the event period; and 4) shares ownership structure also matters in China's stock market to some extent. Collectively, our empirical evidence shows that the relationship between CSR and participation of minority shareholder is similar to state-owned and non-state owned firms. However, the relationship is more significant for non-state owned firms.

\section{Institutional background}

\subsection{Protection mechanism of minority investor in China: online voting system}

According to Allen et al. (2005), due to a lack of minority investor protection mechanisms in China, controlling or majority shareholders of listed firms have a strong incentive to tunnel the wealth and resources of listed firms to themselves by using their 
appointed management (e.g., Jian, Wong 2010; Berkman et al. 2010; Fan et al. 2007; Jiang et al. 2010). Researchers argued that "large investors may represent their own interests, which need not coincide with the interests of other investors in the firm, or with the interests of employees and managers" (Shleifer, Vishny 1997).

To restrict controlling shareholders' egregious expropriation behavior, the CSRC issued a new regulation entitled "Provisions on Strengthening the Protection of the Rights and Interests of the General Public Shareholders" on December 7, 2004. This regulation applies to all domestically listed firms. The provisions stipulate that listed firms should take effective measures to promote the proportion of public shareholders who attend the general meeting of shareholders, thus encouraging listed firms to provide an online voting system apart from the present shareholder meeting. This regulation also enforces that when proposals in shareholder meetings involve seasoned equity offering (SEO), capital reorganization, and other important events that have significant influence on the benefits public shareholders, listed firms should provide an online voting system for the minority shareholders, adopting the proposal only when shareholders representing $2 / 3$ of the voting rights of the tradable shares participate. Despite the automatic expiration of this regulation upon the completion of split share structure reform, which ended by 2007, most A-share firms (Li et al. 2011; Chen et al. 2013) preserved the minority shareholders' online voting system.

The online voting system offers a simple and convenient voting mechanism to minority shareholders, and this enormously decreases the cost of minority shareholders participating in corporate governance. In firms with more tradable shares, this online voting system works especially well with a great amount of small investors or shareholders.

For instance, the 2010 internal report of SZSE mentions that with the introduction of online voting system, participation percentage of minority shareholders in split share structure reform greatly increased to $13 \%$, compared with only approximately $1 \%$ acquired from shareholder meetings without online voting. From 2005 to 2009, 1,573 out of 8,991 shareholder meetings in SZSE offered online voting systems.

As for shareholder meetings with online voting, 1.44 million shareholders or investors express their opinions by using the online system. On average, 920 shareholders participate in each shareholder meeting; the participation rate and vetoing rate are $1.94 \%$ and $15.92 \%$, respectively. Here, vetoing rate in split share structure reform meetings and other meetings are $8.4 \%$ and 19.86 , respectively. However, in shareholder meetings without online voting, 8 shareholders participate in each shareholder meeting; the participation rate and vetoing rate are $0.033 \%$ and $2 \%$, respectively, on average.

Thus, online voting systems in China's stock market enhance the participation of minority shareholders and positively affect the role of minority shareholders in corporate governance.

\subsection{CSR in the U.S. and China}

Based on 30 years' worth of bibliometric analyses on CSR research and theories, De Bakker et al. (2005) point out that CSR has been discussed since the 1950s, at least in the U.S. Formally, Gerde and Wokutch (1998), in their 25-year analysis of proceed- 
ings published on social issues in management, distinguish four CSR-related phases: "gestation and innovation" in the 1960s, "development and expansion" from 1972 to 1979, "institutionalization" from 1980 to 1987, and "maturity" from 1988 to 1996. In the early period, CSR research aims "to describe the situation and perhaps to develop theories of the dimensions of corporate social responsibility or the specific relationship between business and society and between the firm and its employees" (Gerde, Wokutch 1998). However, regarding the later periods, "one would expect that there would be more theory testing in the latter part of the 25 years because there are more developed theories to test and the methodology has improved (or become more refined)".

Currently, four CSR evaluating systems are widely used in the literature. Griffin and Mahon (1997) present an excellent review and identify multiple CSR sources into four categories: 1) the Domini Social Index, which is a hybrid measure of perceptual and multiple dimensions of CSR and is developed by Kinder, Lydenberg, and Domini (KDL). This index has created a series of widely acknowledged social responsibility criteria that gradually became an international standard (Becchetti et al. 2008). The Domini social criterion includes eight major domains: community, corporate governance, diversity, employee relations, environment, human rights, product quality, and controversial business issues; 2) the Fortune reputation survey (a purely perceptual measure). Using questionnaires on eight attributes of firms' reputation, the Fortune creates an overall corporate reputation index; 3) the self-reported measure, i.e., the Toxics Release Inventory (TRI), which consists of information on environmental discharges into water, air, and landfills, and disposal of hazardous waste. This is mandated by the Emergency Planning and Community Right-to-Know Act (EPCRA-1986). Thus, this CSR measure is often used by the government and special interest groups; and 4) corporate philanthropy. Some studies also use philanthropy as CSR measure (Griffin, Mahon 1997).

However, in China, CSR evaluating systems remain in their nascent period. The first CSR report in China was released by Shell China in 1999. Since then, the number of listed firms that regularly report their CSR activities has grown. To our knowledge, only two CSR-related indexes are in use. One is Chinese CSR Development Index, which was published in 2009 by the CSR Research Center of Chinese Academy of Social Sciences (CASS). However, this index only covers China's top 100 state-owned enterprises, top 100 private enterprises, and top 100 foreign-invested enterprises. The index integrates companies' responsible governance, economic performance, social contribution and environmental protection. The other is CSR index for Chinese listed companies, which was issued in 2008 by the SNAI. This SNAI index was formulated in accordance with the standard of SA8000 (the first international certification on social responsibility) issued by Social Accountability International (SAI).

However, only one formal report of Chinese firms' social responsibility ranking covers all listed firms; this is released by SNAI. SNAI issues a set of indexes that crosssectionally provide scores and ranking of CSR for Chinese firms listed on December 24, 2008 (Li, Zhang 2010). 


\subsection{The melamine contamination incident in China}

We consider the melamine contamination incident in China as the natural experiment that dramatically changed the public recognition of CSR. This incident is also used to examine the relation between CSR and investors' preferences (Wang et al. 2010).

As a typical $C S R$ event, the melamine contamination incident broke out on September 11, 2008, when Sanlu Corporation, one of China's largest dairy manufacturers, announced that its products on sale were contaminated by melamine. All its products were immediately recalled. Consumers suspected that all types of dairy products were potentially contaminated. Their fears were confirmed two days later, when products of 22 brands (with total market shares exceeding $90 \%$ in liquid milk) were found to contain melamine (Wang et al. 2010). Later, more reports revealed that top management teams of dairy firms involved knew that their products contained melamine far before the incident occurred. However, they chose not to inform the public because they were afraid that product recalls would heavily hurt their reputations and market shares.

The consequences of the incident were severe (Sanlu went bankrupt five months following the incident), and all publicly traded dairy companies that were found faulty experienced a drastic decline (at least $30 \%$ ) in stock prices.

Using this exogenous incident, this paper investigates how the investors' recognition of CSR affects their participation in corporate governance.

\section{Data and methodology}

\subsection{Sample}

The minority shareholder participation data (2005-2009) was obtained from SZSE. Our CSR variables originated from social responsibility rankings of SNAI Chinese firms. SNAI formulates CSR scores based on the SA8000 standard issued by $\mathrm{SAI}^{3}$.

SNAI argued that the general motivation of issuing the CSR index was to encourage listed firms to increase their CSR disclosures and improve firm value. The system groups the 36 questions into eight categories: environment, energy saving, employees, employment and promotion, social problems, consumer satisfaction, other stakeholders, law, and business ethics. Table 1 presents the full list of questions of SNAI CSR index (Li, Zhang 2010).

The other variables in this research were collected from the CCER Database, a widely used database of listed Chinese firms. SNAI-CSR is the first and only report that covers all listed Chinese firms; we thus limit our sample as cross section data in 2008.

\subsection{Event study and CAR}

The impact of minority shareholder and CSR on firms' market value was estimated by using the event-study methodology (Fama et al.1969), a widely used technique in economics and finance.

\footnotetext{
${ }^{3}$ Social Accountability International developed and oversees the SA8000, a global social accountability standard for decent working conditions.
} 
Table 1. Corporate social responsibility score rating criteria

1. Environmental problems, including curbing polluted environment; recycling waste harmful to environment; producing products good to environment protection; using other means to control pollution.

2. Energy saving, including making use of old and waste materials; great effort to reduce energy consuming; continuously improving energy saving of products; pushing research on energy saving.

3. Employee problems, including caring healthy and safety of employee; training employee; reemployment of laid-off employees; reasonably arrangement of working time and positions; establishment and enforcement of standards on overtime; no employment of child labor; providing employee benefit.

4. Employment and fair promotion, including employment and promotion of minorities; employment and promotion of female; employment and promotion of the handicapped; employment and promotion of veterans.

5. Social problems, including donation to community; donation to education institutes; donation to medical activities; donation to arts and sports; donation to disaster areas; attention to public safety; opening company facilities to the public.

6. Consumers problems, including delivery on time; improvement of products quality; attaching importance to safe use of products; bettering after service; attention to interests of specific consumers.

7. Other stakeholders, including respect to interests of creditors; consideration on interests of suppliers.

8. Abidance by law and business ethics, including anti- corruption, extortion, bribery; operating faithfully and lawfully.

Notes: This table reports the score rating criteria of our CSR variable. The score rating criteria comes from SNAI Chinese firms' social responsibility ranking. The SNAI formulate CSR scores according to the standard of SA8000 issued by Social Accountability International (SAI).

The event day $\left(T_{0}\right)$ is the meeting day of shareholders. The estimation window, $\left[T_{0}-\right.$ $\left.130, T_{0}-11\right]$, is a 120-day period within which we estimate how a stock normally relates to the market. The event window, $\left[T_{0}-5, T_{0}+5\right]$, is the period within which we study the market value changes caused by the event shock. Event windows of different lengths were also used, obtaining similar results.

Cumulative abnormal returns $(C A R)$ for each firm was calculated as the $C A R$ for stock $i$ over the event window, $C A R_{i}=\sum_{t} A R_{i, t} . A R_{i, t}$ was computed by using the market model, $R_{i, t}=\alpha_{i}+\beta_{i} M R_{t}+\varepsilon_{i, t}$, to estimate the expected stock returns for firm $i$ at time $t$ in the estimation window. $M R_{t}$ is the market return on day $t$. This regression obtains the estimated coefficient $\hat{\alpha}_{i}$ and $\hat{\beta}_{i}$. Then the equation $A R_{i, t}=R_{i, t}-\left(\hat{a}_{i}+\hat{b}_{i} M R_{t}\right)$ estimates the $A R_{i, t}$ for stock $i$ in the event window.

\subsection{Methodology}

CSR impact on the minority shareholder participation in corporate governance was examined after controlling for other factors. The following equation was employed:

$$
M S P=f(C S R, \text { Control_Variables }),
$$


where MSP is the minority shareholder participation rate that is computed in the shareholder meeting level. MSPS vary for different proposals even in one shareholder meeting, because voters may not be concerned with all proposals. Specifically,

$$
M S P=\frac{1}{N} \sum_{n=1}^{N} \frac{\text { OVS }_{n}}{\text { TotalShares }} .
$$

$O V S_{n}$ refers to shares of participating online voting for the $n$th proposal in a shareholder meeting. TotalShares refers to the total shares of a listed firm. Alternatively, total tradable shares was also used as a denominator, and obtained highly similar results.

CSR is the actual score of social responsibility index issued by SNAI.

We controlled other potential factors that may affect minority shareholder participation by including common governance variables (i.e. Control_Variables in Equation (1)). Based on previous studies on the Chinese stock market (e.g. Chen et al. 2006; Cheung et al. 2008), we used the following control variables:

$I O$ : defined as the total stock ownership (as a percentage of the total outstanding tradable shares) of all the open- and close-ended funds at the end of a half-year prior to shareholder meetings (In China, portfolios of mutual funds are only reported in detail every six months).

Herf10: the concentration of shares held by the top 10 stockholders was measured by computing Herf10 as $\sum_{n=1}^{10}\left(S_{n} / S\right)^{2}$, where $S_{n}$ is the number of shares held by the $n$th largest stockholder and $S$ is the number of total outstanding shares. We also used two other variables, Top1 $\left(=S_{1} / S\right)$ and Top $2_{-} 10\left(=\sum_{\mathrm{n}=2}^{10}\left(S_{n} / S\right)\right)$, as robust proxies and obtained similar results.

OutDirect: defined as the proportion of external (or non-executive) directors on the firm board size.

BoardMeet: defined as the number of board meetings held in a year. The nonlinear effect was controlled by introducing the variable BoardSquare, which is defined as the square of BoardMeet.

Duality: a dummy variable with the value of 1 if the same person holds the chair and chief executive officer (CEO) positions.

Big5: a dummy variable coded 1 if the auditor is one of the five largest auditors.

We estimate the cluster-robust standard errors and control the industry fixed effects to ensure robust statistical inference. Furthermore, ownership structure is introduced to explore whether firms with different owners indicate varying patterns, given that the Chinese government acts differently from governments observed in other markets or transition economies and having a "grabbing hand" that extorts firms for the benefit of politicians and bureaucrats (Li, Zhang 2010; Frye, Shleifer 1997).

The following specification is employed to examine the impact of CSR-related events' shocks on the minority shareholder participation in firm governance:

$$
M S P=f(C S R, \text { Shock },(C S R \times \text { Shock }), \text { Control_Variables }),
$$


where Shock is a dummy variable that indicates whether shareholder meetings are held before (or after) September 11, 2008, the day the melamine contamination scandal in China's dairy industry broke out. The value of Shock is 1 if the shareholder meeting day is after September 11, 2008; otherwise, the value is 0 . The other variables are defined in Equation (1).

As a typical CSR event that dramatically changes the public perception of CSR (Wang et al. 2010), we expect that the effect of CSR on MSP increases after the melamine contamination incident. Therefore, we the coefficients of $b_{2}$ and $b_{3}$ should be positively significant.

We further investigate whether minority shareholder participation and CSR affect market performance of firms by using the following empirical model:

$$
C A R=f(C S R, M S P,(C S R \times M S P), \text { Control_Variables }),
$$

where $C A R$ is cumulative abnormal return for each firm in an event window $\left[T_{0}-5\right.$, $\left.T_{0}+5\right]$. The computation details are presented in Section 2.2. The other variables are defined in Equation (1).

If the online voting system helps minority shareholders to express their opinions, a high participation level from minority shareholders is expected when proposals are disadvantageous. Given that bad proposals tend to induce a low level of CARs; the coefficient of $M S P, b_{2}$, is expected to be negative and significant. In the marginal of $M S P$ (i.e., attitudes of minority shareholders are controlled), CSR in the interaction item $C S R^{*} M S P$ would probably indicate positive effects on the firm's financial performance in the market.

\section{Empirical results and analysis}

\subsection{Summary statistics}

Table 2 presents basic statistics of our sample. Panel A reports summary statistics of all variables. The average $M S P$ is $5 \%$ with a $6.4 \%$ standard deviation, which indicates a low average participation rate that varies among firms. Given a CSR score ranging from 0 to 1 , average $C S R$ score is 0.344 , indicating a CSR level that is slightly less than the median level of all listed firms. Although the average $C A R$ is $-0.7 \%$ (nearly zero), $C A R$ deviation is high at $7.4 \%$. Thus, market reactions vary among different firms' shareholder meetings. The average institutional holding (mutual funds holding was used as a proxy variable) ratio is low (4.7\%), indicating the slight impact of institutional investor participation in corporate governance. Thus, votes from institutional investors are unlikely to affect the robustness of our results.

Panel B of Table 2 reports correlations among variables. The negative relation between $M S P$ and CSR proves that high-level CSR can reduce the minority shareholder participation in firms' decisions. The positive relation between MSP and IO indicates that a higher institutional holding increases the participation rate of minority shareholders. This is consistent with the theory of (Pound 1988), stating that due to pressures from 
Table 2. Summary statistics and correlations

\begin{tabular}{lcccccccccc}
\hline & MSP & CSR & CAR & IO & Herf10 & Outdirect & Boardmeet & Duality & Big5 \\
\hline \multicolumn{7}{c}{ Panel A: summary statistics } \\
\hline Mean & 0.05 & 0.344 & -0.007 & 0.047 & 0.169 & 0.374 & 11.02 & 0.011 & 0.042 \\
\hline Median & 0.019 & 0.333 & -0.002 & 0.0114 & 0.148 & 0.364 & 10 & 0 & 0 \\
\hline Std & 0.064 & 0.127 & 0.074 & 0.073 & 0.109 & 0.06 & 4.028 & 0.105 & 0.200 \\
\hline Min & 0 & 0.001 & -0.552 & 0 & 0.009 & 0.231 & 4 & 0 & 0 \\
\hline Max & 0.291 & 0.766 & 0.235 & 0.332 & 0.562 & 0.571 & 33 & 1 & 1 \\
\hline P25 & 0.003 & 0.277 & -0.042 & 0 & 0.082 & 0.333 & 9 & 0 & 0 \\
\hline P75 & 0.081 & 0.404 & 0.028 & 0.062 & 0.244 & 0.429 & 13 & 0 & 0 \\
\hline
\end{tabular}

Panel B: correlations

\begin{tabular}{lccccccccc}
\hline CSR & -0.257 & & & & & & & \\
\hline CAR & -0.165 & 0.156 & & & & & & \\
\hline IO & 0.259 & 0.065 & -0.079 & & & & & \\
\hline Herf10 & -0.178 & 0.055 & -0.07 & -0.084 & & & & \\
\hline Outdirect & 0.022 & -0.102 & 0.042 & 0.181 & -0.01 & & & \\
\hline Boardmeet & 0.083 & -0.111 & 0.101 & 0.107 & -0.105 & 0.122 & & \\
\hline Duality & 0.101 & 0.139 & -0.047 & 0.049 & -0.081 & 0.096 & 0.049 & \\
\hline Big5 & 0.038 & -0.009 & 0.007 & 0.085 & -0.012 & -0.011 & 0.07 & -0.023 & 1 \\
\hline
\end{tabular}

Notes: This table presents summary statistics and correlations. MSP is the minority shareholder participation rate that is computed in the shareholder meeting level. CSR is the actual score of social responsibility index issued by SNAI. Shock is a dummy variable to indicate whether shareholder meetings are held before (or after) September 11, 2008, the day of melamine contamination scandal in China's dairy industry broke out. The value of Shock is one if the shareholder meetings day is after September 11,2008 , else, $S h o c k=0 . C A R$ is cumulative abnormal return for each firm in event window $\left[T_{0}-5\right.$, $\left.T_{0}+5\right] . I O$ is defined as the total stock ownership (as a percentage of the total outstanding tradable shares) of all the open- and close-ended funds at the end of a half-year prior to shareholder meetings. Herf10 is the concentration of shares held by the top 10 stockholders was measured by computing Herf10 as $\Sigma^{10}{ }_{\mathrm{n}=1}\left(S_{n} / S\right)^{2}$, where $S_{n}$ is the number of shares held by the $n$th largest stockholder and $S$ is the number of total outstanding shares. OutDirect is the proportion of external (or non-executive) directors on the firm board size. BoardMeet the number of board meetings held in a year. The nonlinear effect was controlled by introducing the variable BoardSquare, which is defined as the square of BoardMeet. Duality is a dummy variable with the value of 1 if the same person holds the chair and chief executive officer (CEO) positions. Big5 is dummy variable coded 1 if the auditor is one of the five largest auditors.

conflicts of interest, institutional investors may vote with management against their own fiduciary interests. Moreover, the $M S P$ negatively relates to $C A R$ considered as a proxy measure of the opinions of minority shareholders (see Chen et al. 2013). This result is intuitional and coincides with the argument that minority shareholders participate more in corporate governance when they are dissatisfied with the situation. CSR's positive 
effect on $C A R$ is also consistent with Wang et al. (2010), who reported that firms' CSR performance significantly influences the behaviors of institutional investors. We offer new evidence with minority shareholders (individual investors) in this paper ${ }^{4}$.

\subsection{CSR's effects on the minority shareholder participation in corporate governance}

Table 3 presents estimation results of Equation (1) with a robust standard errors-adjusted cluster. All of the regressions significantly reject the null hypothesis that independent variables cannot explain the dependent variables. Thus, CSR affects the minority shareholder participation in corporate governance.

Table 3. The role of CSR in the minority shareholder participation

\begin{tabular}{|c|c|c|c|c|c|c|}
\hline \multirow[b]{2}{*}{ Variables } & \multicolumn{2}{|c|}{ All firms } & \multicolumn{2}{|c|}{ Private-owned firms } & \multicolumn{2}{|c|}{ State-owned firms } \\
\hline & (1) & (2) & (3) & (4) & (5) & (6) \\
\hline$C S R$ & $\begin{array}{c}-0.138^{* * *} \\
(0.028)\end{array}$ & $\begin{array}{c}-0.152^{* * *} \\
(0.027)\end{array}$ & $\begin{array}{c}-0.204^{* * *} \\
(0.033)\end{array}$ & $\begin{array}{c}-0.195^{* * *} \\
(0.032)\end{array}$ & $\begin{array}{c}-0.118^{* *} \\
(0.046)\end{array}$ & $\begin{array}{c}-0.140^{* * *} \\
(0.045)\end{array}$ \\
\hline$I O$ & & $\begin{array}{c}0.229^{* * *} \\
(0.047)\end{array}$ & & $\begin{array}{c}0.103^{*} \\
(0.057)\end{array}$ & & $\begin{array}{c}0.221^{* * *} \\
(0.078)\end{array}$ \\
\hline Herf10 & & $\begin{array}{c}-0.083^{* * *} \\
(0.031)\end{array}$ & & $\begin{array}{c}-0.117^{* * *} \\
(0.032)\end{array}$ & & $\begin{array}{l}-0.062 \\
(0.061)\end{array}$ \\
\hline Outdirect & & $\begin{array}{l}-0.082 \\
(0.057)\end{array}$ & & $\begin{array}{c}0.003 \\
(0.063)\end{array}$ & & $\begin{array}{l}-0.125 \\
(0.100)\end{array}$ \\
\hline Boardmeet & & $\begin{array}{c}0.004 \\
(0.003)\end{array}$ & & $\begin{array}{c}0.001 \\
(0.003)\end{array}$ & & $\begin{array}{c}0.006 \\
(0.007)\end{array}$ \\
\hline Boardsquar & & $\begin{array}{c}-0.0001 \\
(0.0001)\end{array}$ & & $\begin{array}{l}-0.00008 \\
(0.00009)\end{array}$ & & $\begin{array}{c}-0.0005 \\
(0.0002)\end{array}$ \\
\hline Duality & & $\begin{array}{l}0.071^{* *} \\
(0.030)\end{array}$ & & $\begin{array}{c}0.047 \\
(0.050)\end{array}$ & & $\begin{array}{c}0.059 \\
(0.042)\end{array}$ \\
\hline Big5 & & $\begin{array}{l}0.0007 \\
(0.016)\end{array}$ & & $\begin{array}{c}-0.039^{* *} \\
(0.017)\end{array}$ & & $\begin{array}{c}0.055^{*} \\
(0.029)\end{array}$ \\
\hline Industry $_{\text {Dummy }}$ & Yes & Yes & Yes & Yes & Yes & Yes \\
\hline Constant & $\begin{array}{c}0.098^{* * *} \\
(0.010)\end{array}$ & $\begin{array}{c}0.109^{* * *} \\
(0.031)\end{array}$ & $\begin{array}{c}0.105^{* * *} \\
(0.011)\end{array}$ & $\begin{array}{c}0.116^{* * * *} \\
(0.033)\end{array}$ & $\begin{array}{c}0.118^{* * *} \\
(0.018)\end{array}$ & $\begin{array}{c}0.116^{*} \\
(0.063)\end{array}$ \\
\hline Obs & 312 & 312 & 206 & 206 & 106 & 106 \\
\hline $\operatorname{Adj}-R^{2}$ & $0.074^{* * *}$ & $0.192^{* * *}$ & $0.161^{* * *}$ & $0.256^{* * *}$ & $0.060^{* * *}$ & $0.234^{* * *}$ \\
\hline
\end{tabular}

Notes: This table reports results from equation (1). Cluster-robust standard errors are in parentheses. All variables are identified previously in Table 2. Private-owned firms and State-owned firms mean our results are based on the sum sample with ultimate controller is the private and the government, respectively. ${ }^{*},{ }^{* *}$, and ${ }^{* * *}$ indicate the significance at the $10 \%, 5 \%$, and $1 \%$ level.

${ }^{4}$ Guided by the CSRC and the SZSE, the online voting system is only used by minority shareholders, who mainly are individual investors. Majority shareholders or institutional investors vote via other ways (e.g. by the spot, phone, fax, or mail). 
The first two columns in Table 3 lists the estimation based on all listed firms. When only the $C S R$ is taken as the right-hand variable, the coefficient of $C S R, b_{1}$, is negatively significant $\left(b_{1}=-0.138, t\right.$-value $\left.=-4.98\right)$, which rejects the null hypothesis (i.e. $\left.b_{1}=0\right)$ at $1 \%$ significant level. Similar results $\left(b_{1}=-0.152, t\right.$-value $\left.=-5.65\right)$ are obtained when control variables are introduced into the regression.

These two estimates combined suggest that CSR performance negatively affects minority shareholder participation in corporate governance and that minority shareholders have greater interests in participating in shareholder meetings of firms with low CSR scores than those of firms with high CSR scores. These results imply that minority shareholders tend to be concerned that low CSR performance will expropriate their benefits. Similarly, firms with poor $C S R$ performance are more likely to have a negative corporate governance mechanism.

Columns (3) to (4) and (5) to (6) in Table 3 present the above relations in private-owned and state-owned firms, respectively. The obtained results are similar despite different ownership structures.

The coefficient of $I O$ is significant and positive, supporting the argument of "conflictof-interest pressures" (Pound 1988), namely, institutional investors voting with management against their own fiduciary interests. Recognizing this potential conflict of interest, minority shareholders tend to participate in shareholder meetings when institutional investors hold a large fraction of a firms' share.

\subsection{Shocks of exogenous $C S R$-related events}

We introduce a $C S R$-related natural experiment based on the established relation in Table 3, and further investigate how CSR-grabbing events affect minority shareholder participation. We conduct the regression following Equation (3), and Table 4 presents test results with robust standard errors-adjusted cluster. All the regressions are significant, indicating that our independent variables have explanatory power.

The first two columns in Table 4 present the estimation based on all listed firms. Column (1) shows that CSR coefficient is robust (remaining negative). Shock is a dummy time variable indicating a $C S R$-event, the melamine contamination incident in China. The coefficient of Shock, $b_{2}$, is positively significant $\left(b_{2}=0.048 t\right.$-value $\left.=2.20\right)$, which rejects the null hypothesis (i.e. $b_{2}=0$ ) at $5 \%$ significant level. The coefficient of the interaction item $C S R *$ Shock is negatively significant, rejecting the null hypothesis, $b_{3}=$ 0 . Thus, on the one hand, Shocks of CSR-related events enhance minority shareholder participation in firms' governance. On the other hand, the negative $b_{3}$ indicate that minority shareholders are more (less) likely to attend the shareholder meetings of firms with low (high) CSR levels after the event shock.

The coefficient is significantly positive for institutional holding, similarly supporting the argument on "conflict-of-interest pressures". In the uncalculated tables, the minority shareholder participation rate marginally increases in the institutional investors holding variable $(I O)$ by introducing the interaction item $C S R^{*} I O$. These results are consistent with the argument that minority shareholders do not trust the institutional investors in 
China, which is quite contrary to findings in western markets. Results are robust when control variables are introduced into the regression, i.e. column (2).

Columns (3) to (4) and (5) to (6) in Table 4 presents the results based on private-owned and state-owned firms, respectively. Private-owned firms are similar with patterns in all listed firms. State-owned firms indicate no significant coefficients although the coefficient signs are consistent with those of private-owned firms. Therefore, minority shareholders are not interested in participating in shareholder meetings of state-owned firms, possibly because the controlling shareholders are more powerful in state-owned firms. Moreover, the political connection of state-owned firms (Li, Zhang 2010) also documents the different relations between $C S R$ and varying firm ownership structure.

Table 4. Shocks of exogenous CSR-events on minority shareholder participation

\begin{tabular}{|c|c|c|c|c|c|c|}
\hline \multirow[b]{2}{*}{ Variables } & \multicolumn{2}{|c|}{ All firms } & \multicolumn{2}{|c|}{ Private-owned firms } & \multicolumn{2}{|c|}{ State-owned firms } \\
\hline & (1) & (2) & (3) & (4) & (5) & (6) \\
\hline$C S R$ & $\begin{array}{c}-0.093^{* *} \\
(0.038)\end{array}$ & $\begin{array}{c}-0.096^{* * *} \\
(0.036)\end{array}$ & $\begin{array}{c}-0.161^{* * *} \\
(0.046)\end{array}$ & $\begin{array}{c}-0.148^{* * *} \\
(0.046)\end{array}$ & $\begin{array}{c}-0.074 \\
(0.061)\end{array}$ & $\begin{array}{l}-0.092 \\
(0.058)\end{array}$ \\
\hline Shock & $\begin{array}{l}0.048^{* *} \\
(0.022)\end{array}$ & $\begin{array}{c}0.065^{* * *} \\
(0.021)\end{array}$ & $\begin{array}{l}0.050^{* *} \\
(0.024)\end{array}$ & $\begin{array}{l}0.053^{* *} \\
(0.023)\end{array}$ & $\begin{array}{c}0.040 \\
(0.042)\end{array}$ & $\begin{array}{c}0.045 \\
(0.041)\end{array}$ \\
\hline CSR*Shock & $\begin{array}{c}-0.103^{*} \\
(0.061)\end{array}$ & $\begin{array}{c}-0.142^{* *} \\
(0.057)\end{array}$ & $\begin{array}{c}-0.122^{*} \\
(0.070)\end{array}$ & $\begin{array}{c}-0.128^{*} \\
(0.068)\end{array}$ & $\begin{array}{l}-0.051 \\
(0.108)\end{array}$ & $\begin{array}{l}-0.070 \\
(0.105)\end{array}$ \\
\hline IO & & $\begin{array}{c}0.275^{\text {*** }} \\
(0.049)\end{array}$ & & $\begin{array}{l}0.147^{* *} \\
(0.062)\end{array}$ & & $\begin{array}{c}0.268^{* * *} \\
(0.082)\end{array}$ \\
\hline Herf10 & & $\begin{array}{c}-0.074^{* *} \\
(0.031)\end{array}$ & & $\begin{array}{c}-0.122^{* * *} \\
(0.034)\end{array}$ & & $\begin{array}{l}-0.026 \\
(0.063)\end{array}$ \\
\hline Outdirect & & $\begin{array}{l}-0.048 \\
(0.058)\end{array}$ & & $\begin{array}{l}-0.003 \\
(0.065)\end{array}$ & & $\begin{array}{l}-0.034 \\
(0.109)\end{array}$ \\
\hline Boardmeet & & $\begin{array}{c}0.003 \\
(0.003)\end{array}$ & & $\begin{array}{c}0.002 \\
(0.003)\end{array}$ & & $\begin{array}{c}0.003 \\
(0.007)\end{array}$ \\
\hline Boardsquar & & $\begin{array}{c}-0.00009 \\
(0.0001)\end{array}$ & & $\begin{array}{c}-0.00007 \\
(0.0001)\end{array}$ & & $\begin{array}{c}-0.00005 \\
(0.0003)\end{array}$ \\
\hline Duality & & $\begin{array}{l}0.073^{* *} \\
(0.030)\end{array}$ & & $\begin{array}{c}0.058 \\
(0.051)\end{array}$ & & $\begin{array}{c}0.056 \\
(0.041)\end{array}$ \\
\hline Big5 & & $\begin{array}{c}0.007 \\
(0.017)\end{array}$ & & $\begin{array}{c}-0.034^{*} \\
(0.019)\end{array}$ & & $\begin{array}{l}0.052^{*} \\
(0.030)\end{array}$ \\
\hline Industry $_{\text {Dummy }}$ & Yes & Yes & Yes & Yes & Yes & Yes \\
\hline Constant & $\begin{array}{c}0.080^{* * *} \\
(0.014)\end{array}$ & $\begin{array}{l}0.075^{* *} \\
(0.032)\end{array}$ & $\begin{array}{c}0.090^{* * *} \\
(0.016)\end{array}$ & $\begin{array}{c}0.095^{* * *} \\
(0.036)\end{array}$ & $\begin{array}{c}0.095^{\text {*** }} \\
(0.024)\end{array}$ & $\begin{array}{c}0.070 \\
(0.067)\end{array}$ \\
\hline Obs & 284 & 284 & 187 & 187 & 97 & 97 \\
\hline $\operatorname{Adj-R^{2}}$ & $0.090^{* * *}$ & $0.237^{* * *}$ & $0.200^{* * *}$ & $0.301^{* * *}$ & $0.056^{* * *}$ & $0.255^{* * *}$ \\
\hline
\end{tabular}

Notes: This table reports results from equation (3). Cluster-robust standard errors are in parentheses. All variables are identified previously in Table 2. Private-owned firms and State-owned firms mean our results are based on the sub sample with ultimate controller is the private and the government, respectively. ${ }^{* * *}$, and $^{* * *}$ indicate the significance at the $10 \%, 5 \%$, and $1 \%$ level. 


\section{4. $C S R$, minority shareholder participation and firm market value}

Table 5 presents estimation results for the influence of CSR and minority shareholder participation on firms' market value, which is measured by cumulative abnormal returns $(C A R)$, as specified in Equation (4).

Columns (1) to (3) in Table 5 present estimations based on all listed firms. Column (1) shows that the CSR coefficient is positive and significant, indicating that a high CSR level can induce high market values of firms. However, columns (2) to (3) show that this argument is not robust, and CSR coefficients become insignificant when two other variables, $M S P$ and $C S R^{*} M S P$, are introduced. Columns (2) to (3) show that the main factors affecting firm market values in the event windows of shareholder meetings are

Table 5. CSR, Minority shareholder participation, and firm market performance

\begin{tabular}{|c|c|c|c|c|c|c|c|c|c|}
\hline \multirow[b]{2}{*}{ Variables } & \multicolumn{3}{|c|}{ All firms } & \multicolumn{3}{|c|}{ Private-owned firms } & \multicolumn{3}{|c|}{ State-owned firms } \\
\hline & (1) & (2) & (3) & (4) & (5) & (6) & (7) & $(8)$ & (9) \\
\hline CSR & $\begin{array}{c}0.101^{* * *} \\
(0.028)\end{array}$ & $\begin{array}{c}0.019 \\
(0.037)\end{array}$ & $\begin{array}{c}0.035 \\
(0.038)\end{array}$ & $\begin{array}{l}0.088^{* *} \\
(0.040)\end{array}$ & $\begin{array}{c}0.010 \\
(0.053)\end{array}$ & $\begin{array}{c}0.009 \\
(0.054)\end{array}$ & $\begin{array}{c}0.132^{* * *} \\
(0.039)\end{array}$ & $\begin{array}{c}0.032 \\
(0.054)\end{array}$ & $\begin{array}{c}0.038 \\
(0.053)\end{array}$ \\
\hline$M S P$ & & $\begin{array}{c}-0.464^{* * *} \\
(0.131)\end{array}$ & $\begin{array}{c}-0.448^{* * *} \\
(0.133)\end{array}$ & & $\begin{array}{c}-0.416^{* *} \\
(0.187)\end{array}$ & $\begin{array}{c}-0.440^{* *} \\
(0.189)\end{array}$ & & $\begin{array}{c}-0.543^{* * *} \\
(0.196)\end{array}$ & $\begin{array}{c}-0.557^{* * *} \\
(0.197)\end{array}$ \\
\hline$C S R * M S P$ & & $\begin{array}{l}0.866^{* *} \\
(0.378)\end{array}$ & $\begin{array}{c}0.899^{* *} \\
(0.389)\end{array}$ & & $\begin{array}{c}0.996 \\
(0.611)\end{array}$ & $\begin{array}{c}1.109^{*} \\
(0.624) \\
\end{array}$ & & $\begin{array}{c}0.954^{*} \\
(0.502)\end{array}$ & $\begin{array}{c}0.949^{*} \\
(0.502) \\
\end{array}$ \\
\hline$I O$ & & & $\begin{array}{l}-0.034 \\
(0.052)\end{array}$ & & & $\begin{array}{l}-0.110 \\
(0.075)\end{array}$ & & & $\begin{array}{c}0.050 \\
(0.072)\end{array}$ \\
\hline Herf10 & & & $\begin{array}{l}-0.017 \\
(0.036)\end{array}$ & & & $\begin{array}{l}-0.039 \\
(0.049)\end{array}$ & & & $\begin{array}{c}0.024 \\
(0.054)\end{array}$ \\
\hline Outdirect & & & $\begin{array}{c}0.013 \\
(0.059)\end{array}$ & & & $\begin{array}{l}-0.085 \\
(0.081)\end{array}$ & & & $\begin{array}{c}0.114 \\
(0.084)\end{array}$ \\
\hline Boardmeet & & & $\begin{array}{l}-0.003 \\
(0.003)\end{array}$ & & & $\begin{array}{l}-0.001 \\
(0.004)\end{array}$ & & & $\begin{array}{l}-0.007 \\
(0.006)\end{array}$ \\
\hline Boardsquar & & & $\begin{array}{c}0.000 \\
(0.000)\end{array}$ & & & $\begin{array}{c}0.000 \\
(0.000)\end{array}$ & & & $\begin{array}{c}0.000 \\
(0.000)\end{array}$ \\
\hline Duality & & & $\begin{array}{l}-0.066^{*} \\
(0.035)\end{array}$ & & & $\begin{array}{c}0.000 \\
(0.000)\end{array}$ & & & $\begin{array}{l}-0.058^{*} \\
(0.035)\end{array}$ \\
\hline Big5 & & & $\begin{array}{c}0.001 \\
(0.017)\end{array}$ & & & $\begin{array}{l}-0.030 \\
(0.023)\end{array}$ & & & $\begin{array}{l}0.045^{*} \\
(0.025)\end{array}$ \\
\hline Industry $_{\text {Dummy }}$ & Yes & Yes & Yes & Yes & Yes & Yes & Yes & Yes & Yes \\
\hline Constant & $\begin{array}{c}-0.028^{* * *} \\
(0.010)\end{array}$ & $\begin{array}{c}0.012 \\
(0.014)\end{array}$ & $\begin{array}{c}0.015 \\
(0.034) \\
\end{array}$ & $\begin{array}{l}-0.018 \\
(0.014)\end{array}$ & $\begin{array}{c}0.014 \\
(0.019)\end{array}$ & $\begin{array}{c}0.057 \\
(0.044)\end{array}$ & $\begin{array}{c}-0.050^{* * *} \\
(0.016)\end{array}$ & $\begin{array}{c}0.006 \\
(0.024)\end{array}$ & $\begin{array}{l}-0.007 \\
(0.059)\end{array}$ \\
\hline$O b s$ & 307 & 307 & 307 & 201 & 201 & 201 & 106 & 106 & 106 \\
\hline $\operatorname{Adj}-R^{2}$ & $0.047^{* * *}$ & $0.104^{* * *}$ & $0.137^{* * *}$ & $0.027^{* * *}$ & $0.058^{* * *}$ & $0.109^{* * *}$ & $0.110^{* * *}$ & $0.197^{* * *}$ & $0.308^{* * *}$ \\
\hline
\end{tabular}

Notes: This table reports results from equation (4). Cluster-robust standard errors are in parentheses. All variables are identified previously in Table 2. Private-owned firms and State-owned firms mean our results are based on the sub sample with ultimate controller is the private and the government, respectively. ${ }^{*}, * *$, and $* * *$ indicate the significance at the $10 \%, 5 \%$, and $1 \%$ level. 
the minority shareholder participation and its interaction with $C S R$. These two variables absorb the CSR effect. Specifically, the coefficient of $M S P, b_{2}$, is negatively significant $\left(b_{2}=-0.464, t\right.$-value $\left.=-3.54\right)$, which rejects the null hypothesis (i.e. $\left.b_{2}=0\right)$ at $1 \%$ significant level. Thus, a higher rate of minority shareholder participation decreases the market reaction or market value. This similarly supports the conjecture that minority shareholders tend to only attend shareholder meetings when they are concerned about the proposals. Based on the MSP regression coefficient, if proposals are disadvantageous for minority shareholders, a high level of minority shareholder participation is expected. This perspective potentially implies that minority shareholders can express their opinions, and that only a convenient and simple communication or voting system is necessary.

The coefficients of $C S R^{*} M S P, b_{3}$, are positive and significant, as expected. The positive $b_{3}$ suggests that, once the minority shareholder participation is controlled, CSRs maintain marginal positive effects on the firm's financial performance in the market. This finding is consistent with that of (Wang et al. 2010).

No significant effects based on the estimation results of institutional investors were detected in the event window. Hence, the behaviors of institutional investors are unlikely to affect the robustness of our results.

Columns (4) to (6) and (7) to (9) of Table 5 indicate the results based on privateand state-owned firms, respectively. Our results are robust despite the different ownership structures. However, for private-owned firms, the coefficient of interaction item $C S R^{*} M S P$ is positive, but not significant $(\mathrm{t}$-value $=1.63)$.

Collectively, our results show that CSR and minority shareholder participation in corporate governance significantly affect firms' market performance. These findings have important policy implications. The government and monitors should further enhance the protections of minority shareholders and firms' CSR performances, especially in emerging markets.

\subsection{Robustness tests}

Three types of sensitivity testes demonstrate the robustness of our results. First, we verify whether our inferences are robust to event window changes in calculating CARs. We also used the event windows $\left[T_{0}-3, T_{0}+3\right]$ and $\left[T_{0}-10, T_{0}+10\right]$, obtaining similar results.

Second, average participation ratios of all proposals in firms' shareholder meetings were used to measure the MSP variable. However, an alternative measure is to examine our questions at the proposal level. Several investors may only pay attention to their concerned proposals. Thus, the minority shareholder participation ratios typically vary for different proposals in one shareholder meeting. We obtained even more significant results when using this alternative measure.

Third, online voting shares over tradable shares were used to measure MSP2. This calculation is rational because online voting shares must come from tradable shares. MSP2 was used to examine all the questions in this paper and obtain highly robust results. 


\section{Conclusions}

The aim of this study is to shed lights on whether CSR affect minority shareholders' participation in firms' decision, and if CSR indeed matters, does it enhance or weaken the participation of minority shareholders? Furthermore, we also consider two other important questions: 1) does the mounting attention to CSR due to some events have marginal effects on the relation between CSR and minority shareholders' participation? 2) do CSR and minority shareholders' participation affect firms' market performances?

This study aimed to further understand whether $C S R$ affects minority shareholder participation in decisions of firms, and if so, whether CSR enhances or weakens the minority shareholder participation. Furthermore, two other important questions were considered: 1) whether increasing attention on $C S R$ caused by certain events have marginal effects on the relation between CSR and minority shareholder participation, and 2) whether CSR and minority shareholder participation affect firms' market performances.

Our three main findings are as follows: 1) firms' CSR levels significantly affect the participation of minority shareholders, and CSR can substitute the governance role of minority shareholders to a certain extent; 2) the exogenous shock related to CSR can significantly affect the participation of minority shareholders; and 3) firms with higher CSR levels and lower participation rate of minority shareholders enjoy higher market value improvement. Limited evidence indicates that minority shareholders do not trust institutional investors in China, which is consistent with the argument of "conflict-ofinterest pressures" advocated by (Pound 1988).

This paper offers valuable information to the highly debated issue of providing direct control to minority shareholders in corporate governance. Our results are directly relevant to the Chinese securities regulator (CSRC) and related regulators who encounter the challenge of protecting minority shareholder interests. Given China's poor level of investor protection and weak law enforcement, we show how strengthening the direct control of minority shareholders over corporate decisions can enhance their voice in firms' important events. Both CSR performance of firms and minority shareholder participation significantly affect the firms' market performance. To the best of our knowledge, this is the first paper that directly investigates minority shareholder protection, $C S R$, and firms' market performance by using the voting behaviors of individual investors. The important policy implications in this paper could be of interest to regulators in China and other countries who intend to strengthen minority shareholder control over corporate decisions and firms' CSR performance.

\section{Acknowledgements}

We thank Weiqiang Tan, Maobin Wang, Wenjing Li, Yan Sheng, Shasha Liu, Danglun Luo, Rui Lu, Jianhua Liu, Dong Chen, Qingyuan Li and seminar participants at Sun YatSen University and Wuhan University for helpful comments and valuable suggestions.

\section{Funding}

This work was supported by the National Natural Science Foundation of China [grant number 71372130, 71173078]. 


\section{References}

Allen, F.; Qian, J.; Qian, M. J. 2005. Law, finance, and economic growth in China, Journal of Financial Economics 77: 57-116. http://dx.doi.org/10.1016/j.jineco.2004.06.010

Bebchuk, L. A. 2005. The case for increasing shareholder power, Harvard Law Review 118: 1-65. Becchetti, L.; Giacomo, S. D.; Pinnacchio, D. 2005. Corporate social responsibility and corporate performance: evidence from a panel of US listed companies, Applied Economics 40: 541-567. http://dx.doi.org/10.1080/00036840500428112

Berkman, H.; Cole, R. A.; Fu, L. J. 2010. Political connections and minority-shareholder protection: evidence from securities-market regulation in China, Journal of Financial and Quantitative Analysis 45: 1391-1417. http://dx.doi.org/10.1017/S0022109010000608

Chen, G. M.; Firth, M.; Gao, D. N.; Rui, O. M. 2006. Ownership structure, corporate governance, and fraud: Evidence from China, Journal of Corporate Finance 12: 424-448.

http://dx.doi.org/10.1016/j.jcorpfin.2005.09.002

Chen, Z.; Ke, B.; Yang, Z. 2010. Does granting minority shareholders direct control over corporate decisions help reduce value decreasing corporate decisions in firms with concentrated share ownership? A natural experiment from China, The Accounting Review 88: 1211-1238.

http://dx.doi.org/10.2308/accr-50424

Cheung, Y. L.; Jiang, P.; Limpaphayom, P.; Lu, T. 2008. Does corporate governance matter in China?, China Economic Review 19: 460-479. http://dx.doi.org/10.1016/j.chieco.2008.01.002

Cremers, M.; Romano, R. 2009. Institutional investors and proxy voting on compensation plans: the impact of the 2003 mutual fund voting disclosure regulation, NBER Working paper.

Davis, G. F.; Kim, E. H. 2007. Business ties and proxy voting by mutual funds, Journal of Financial Economics 85: 552-570. http://dx.doi.org/10.1016/j.jfineco.2005.04.003

De Bakker, F. G. A.; Groenewegen, P.; Den Hond, F. 2005. A bibliometric analysis of 30 years of research and theory on corporate social responsibility and corporate social performance, Business and Society 44: 283-317. http://dx.doi.org/10.1177/0007650305278086

Deniz-Deniz, M. D.; Garcia-Falcon, J. M. 2002. Determinants of the multinationals' social response. Empirical application to international companies operating in Spain, Journal of Business Ethics 38: 339-370. http://dx.doi.org/10.1023/A:1016061629745

Fama, E.; Fisher, L.; Jensen, M.; Roll, R. 1969. The adjustment of stock prices to new information, International Economic Review 10: 1-21. http://dx.doi.org/10.2307/2525569

Fan, J. P. H.; Wong, T. J.; Zhang, T. Y. 2007. Politically connected CEOs, corporate governance, and Post-IPO performance of China's newly partially privatized firms, Journal of Financial Economics 84: 330-357. http://dx.doi.org/10.1016/j.jfineco.2006.03.008

Frye, T.; Shleifer, A. 1997. The invisible hand and the grabbing hand, American Economic Review 87: 354-358.

Gerde, V. W.; Wokutch, R. E. 1998. 25 years and going strong: a content analysis of the first 25 years of the Social Issues in Management Division Proceedings, Business and Society 37: 414-446. http://dx.doi.org/10.1177/000765039803700405

Gillan, S. L.; Starks, L. T. 2007. The evolution of shareholder activism in the United States, Journal of Applied Corporate Finance 19: 55-73. http://dx.doi.org/10.1111/j.1745-6622.2007.00125.x

Graves, S. B.; Waddock, S. A. 1994. Institutional owners and corporate social performance, Academy of Management Journal 37: 1034-1046. http://dx.doi.org/10.2307/256611

Griffin, J. J.; Mahon, J. F. 1997. The corporate social performance and corporate financial performance debate: twenty-five years of incomparable research, Business and Society 36: 5-31. http://dx.doi.org/10.1177/000765039703600102 
Godfrey, P. 2005. The relationship between corporate philanthropy and shareholder wealth: a risk management perspective, Academy of Management Review 30(4): 777-798.

http://dx.doi.org/10.5465/AMR.2005.18378878

Hill, R.; Ainscough, T.; Shank, T.; Manullang, D. 2007. Corporate social responsibility and socially responsible investing: a global perspective, Journal of Business Ethics 70: 165-174.

http://dx.doi.org/10.1007/s10551-006-9103-8

Jian, M.; Wong, T. J. 2010. Propping through related party transactions, Review of Accounting Studies 15: 70-105. http://dx.doi.org/10.1007/s11142-008-9081-4

Jiang, G. H.; Lee, C.; Yue, H. 2010. Tunneling through intercorporate loans: the China experience, Journal of Financial Economics 98: 1-20. http://dx.doi.org/10.1016/j.jfineco.2010.05.002

Johnson, R. A.; Greening, D. W. 1999. The effects of corporate governance and institutional ownership types on corporate social performance, Academy of Management Journal 42: 564-576. http://dx.doi.org/10.2307/256977

Li, K.; Wang, T.; Cheung, Y.-L.; Jiang, P. 2011. Privatization and risk sharing: evidence from the split share structure reform in China, Review of Financial Studies 24(7): 2499-2525.

http://dx.doi.org/10.1093/rfs/hhr025

Li, W.; Zhang, R. 2010. Corporate social responsibility, ownership structure, and political interference: evidence from China, Journal of Business Ethics 96: 631-645.

http://dx.doi.org/10.1007/s10551-010-0488-z

McWilliams, A.; Siegel, D. 1997. Event studies in management research: theoretical and empirical issues, Academy of Management Journal 40: 626-657. http://dx.doi.org/10.2307/257056

Posnikoff, J. F. 1997. Disinvestment from South Africa: they did well by doing good, Contemporary Economic Policy 15: 76-86. http://dx.doi.org/10.1111/j.1465-7287.1997.tb00456.x

Pound, J. 1988. The information effects of takeover bids and resistance, Journal of Financial Economics 22: 207-227. http://dx.doi.org/10.1016/0304-405X(88)90069-4

Scannell, K. 2009. Policy makers work to give shareholders more boardroom clout, The Wall Street Journal March 26: B4 .

Shleifer, A.; Vishny, R. W. 1997. A survey of corporate governance, Journal of Finance 52: 737-783.

Smaliukiene, R. 2007. Stakeholders' impact on the environmental responsibility: model design and testing, Journal of Business Economics and Management 8: 213-223.

http://dx.doi.org/10.1111/j.1540-6261.1997.tb04820.x

Stanwick, P. A.; Stanwick, S. D. 1998. The relationship between corporate social performance and organizational size, financial performance, and environmental performance: an empirical examination. Journal of Business Ethics 17: 195-204. http://dx.doi.org/10.1023/A:1005784421547

Surroca, J.; Tribo, J. Waddock. S. 2010. Corporate responsibility and financial performance: the role of intangible resources, Strategic Management Journal 31: 463-490.

http://dx.doi.org/10.1002/smj.820

Teoh, S. H.; Welch, I.; Wazzan, C. P. 1999. The effect of socially activist investment policies on the financial markets, Journal of Business 72: 35-89. http://dx.doi.org/10.1086/209602

Tian, L. H.; Estrin, S. 2008. Retained state shareholding in Chinese PLCs: does government ownership always reduce corporate value?, Journal of Comparative Economic 36: 74-89.

http://dx.doi.org/10.1016/j.jce.2007.10.003

Ullmann, A. 1985. Data in search of a theory a critical examination of the relationship among social performance, social disclosure, and economic performance, Academy of Management Review 10(3): 540-577.

Vascellaro, J. E.; Tibken, S. 2008. Yahoo, Icahn settle proxy battle in wake of rejected Microsoft offer, The Wall Street Journal July 22: B1 
Wang, M.; Qiu, C.; Kong, D. 2010. Corporate social responsibility, investor behaviors, and stock market returns, Journal of Business Ethics 101: 1-15.

Wright, P.; Ferris, S. P. 1997. Agency conflict and corporate strategy: the effect of divestment on corporate value, Strategic Management Journal 18: 77-83.

http://dx.doi.org/10.1002/(SICI)1097-0266(199701)18:1<77::AID-SMJ810>3.0.CO;2-R

$\mathrm{Zu}$, L. R.; Song, L. N. 2009. Determinants of managerial values on corporate social responsibility: evidence from China, Journal of Business Ethics 88: 105-117.

http://dx.doi.org/10.1007/s10551-008-9828-7

Dongmin KONG, Dr, earned his PhD in Finance at School of Business, Sun Yat-Sen University. He is an associate professor of Finance at Department of Finance, Huazhong University of Science and Technology, China. He was visiting Professor of Finance at McCombs School of Business, University Texas at Austin (2008-2009), and currently he is visiting Professor of Finance at School of Business, Hong Kong Baptist University, Hong Kong (2011-2012).

His research interests include corporate finance and asset pricing. Dr. Dongmin Kong has published articles on a wide range of finance and business-related issues in many academic journals including the Journal of Business Ethics, Food Policy, Emerging Market Finance and Trade, China Finance Review International, Frontiers of Economics in China, Frontiers of Business Research in China, China Accounting and Finance Review, etc. 